\title{
Antioxidant capacity and total polyphenolic content in quince (Cydonia oblonga Mill.) fruit
}

\author{
Papp, N. ${ }^{1}$, Szabó, T. ${ }^{2}$, Szabó, Z. $^{3}$, Nyéki, J. ${ }^{3}$, Stefanovits-Bányai, É. ${ }^{1}$ \& Hegedűs, A. ${ }^{4}$ \\ ${ }^{1}$ Corvinus University of Budapest, Faculty of Food Science, Department of Applied Chemistry, \\ 1118 Budapest, Villányi út 29., Hungary \\ ${ }^{2}$ Research and Extension Centre for Fruit Growing, Újfehértó, H-4244 Újfehértó, Vadastag út 2, Hungary \\ ${ }^{3}$ University of Debrecen, Centre of Agricultural Sciences, H-4032, Debrecen, Hungary \\ ${ }^{4}$ Corvinus University of Budapest, Faculty of Horticultural Science, Department of Genetics and Plant Breeding, \\ 1118 Budapest, Villányi út 29., Hungary; E-mail: hegedus.attila@uni-corvinus.hu
}

\begin{abstract}
Summary: Fruits of twelve quince (Cydonia oblonga Mill.) commercial cultivars and selections were compared in the ferric reducing antioxidant power (FRAP) and total phenolic content (TPC) of intact and peeled fruits. The antioxidant capacity and total phenolic content ranged between 5.99 and $63.10 \mathrm{mmol} \mathrm{AA} / 100 \mathrm{~g} \mathrm{FW}$, and 3.92 and $12.83 \mathrm{~g} \mathrm{GA} / 100 \mathrm{~g}$ FW, respectively. These ranges cover an almost 8 -times variation among the tested genotypes in case of antioxidant capacity and also declares two-times variation for total polyphenolic content. Cultivars 'Aromate' and 'Bereczki' possessed the lowest antioxidant capacity and 'Román portugál' and 'Bereczki' had the lowest polyphenolic contents. In contrast, cultivars 'Champion' and 'Konstantinápolyi' possessed the highest antioxidant capacity and 'Mezőtúri' and 'De Husi' had the highest polyphenolic contents. The Pearson's coefficient was relatively moderate but significant ( $r=0.51)$ indicating a weak interdependence between FRAP and TPC values of quince fruits. Our results led us to the conclusion that quince might be considered as a valuable source of antioxidants and polyphenolics.
\end{abstract}

Key words: antioxidant, Cydonia oblonga, quince, total phenolics

\section{Introduction}

Quince (Cydonia oblonga Mill.) belongs to the Maloideae subfamily of Rosaceae and is a native to Southwest Europe and Minor Asia (Patel et al., 2011). It produces golden yellow pome fruits, when mature. Although quince is regarded as a minor fruit crop with limited economical importance, this fruit may provide good opportunities to be exploited. It has been long known that quince is a rich source of pectins (Rop et al., 2011) containing higher quantities from such compounds than apple fruits.

The average vitamin $\mathrm{C}$ content of quince fruit is approximately two-times higher than vitamin $\mathrm{C}$ contents in apple (Bíró and Lindmayer, 1992); however, other studies detected similar levels of ascorbic acid in quince and apple (Souci et al., 2002). For Czech quince cultivars, vitamin C content in intact fruits of quinces ranged between 50 and 80 $\mathrm{mg} / 100 \mathrm{~g}$ fresh weight. The cultivar 'Muškatova' contained the highest amount of ascorbic acid $(79.31 \pm 2.01 \mathrm{~g} / 100 \mathrm{~g} \mathrm{FW})$. This value is markedly higher than the average value set for quince in the USDA database (USDA, 2012), which indicates great variations presumably due to genetic background.

Quince is also a rich source of polyphenolic compounds. Quince pulp has a much lower amount of phenolics than quince peel (Silva et al., 2002). Quince pulp and peel differ in their phenolic profiles: the pulp contains mainly caffeoylquinic acids, whereas the peel possesses both caffeoylquinic acids and several flavonol glycosides in great amounts. In Tunisian quinces, the total phenolic content of the flesh and peel parts ranged from 37 to 47 and 105 to 157 $\mathrm{mg} / 100 \mathrm{~g}$ of fresh weight, respectively (Fattouh et al., 2007). Chlorogenic acid (5-O-caffeoylquinic acid) was the most abundant phenolic compound in flesh (37\%), whereas rutin (quercetin 3-O-rutinoside) was the main one in peel (36\%). The radical scavenging potential of the extracts was higher for those obtained from the peel. The phenolic fraction gives a higher contribution for the antioxidant potential of quince fruit than organic acids (Silva et al., 2004).

Polyphenolics in quince fruit may have preventive or protective effects against several diseases including antiulcerative effects (Натаиzи et al., 2006), chronic inflammation (Essafi-Benkhadir et al., 2012), atopic dermatitis (Shinomiya et al., 2009) etc. Alesiani et al. (2010) identified several compounds with antiproliferative effects from quince peels although Carvalho et al. (2010) could not show inhibitory effects of quince on human kidney and colon cancer cells.

The present study was carried out to characterize the antioxidant power and total polyphenolic contents of the most popular quince cultivars grown in Hungary. In addition, the tested germplasm contained Hungarian and foreign cultivars as well as a selected clone to characterize genetic variability in this trait. 


\section{Materials and methods}

\section{Genotypes tested}

Altogether, 12 Cydonia oblonga Mill. commercial cultivars and local selections ('Angersi', 'Aromate', 'Bereczki', 'Bereczki bőtermő', 'Champion', 'De Husi', 'Konstantinápolyi', 'Leskovacka', 'Mezőtúri', 'Moldova nesti', 'Román portugál' and 'Triumph') were used for the analyses. All cultivars and hybrids were grown at the same germplasm collection in the Research and Extension Centre for Fruit Growing in Újfehértó and fruits were harvested in the season of 2010 .

\section{Fruit sample preparation}

For antioxidant assays, $100 \mathrm{~g}$ fruit were homogenized as intact whole fruits (peel and flesh together) or peeled fruits (flesh without skin) in distilled water and centrifuged with a Hettich Zentrifugen (Mikro 22 R; Tuttlingen, Germany) device $\left(4{ }^{\circ} \mathrm{C}, 35 \mathrm{~min}, 18750 g\right)$, after which supernatants were used for most of the redox assays. Samples for further analyses were kept at $-80^{\circ} \mathrm{C}$ until use.

\section{Antioxidant and total phenolic assays}

Antioxidant capacity was determined using the FRAP (Ferric Reducing Antioxidant Power) method (Benzie and Strain, 1996) and expressed as mmol ascorbic acid (AA)/100 g fresh weight. Total phenolic content (TPC) was measured using Folin-Ciocalteu's reagent according to the method of Singleton and Rossi (1965). The content of soluble phenols was calculated from a standard curve based on gallic acid concentration.

\section{Statistical analysis}

Data presented for each cultivar represent the mean values determined from three independent homogenates. Correlation coefficients of redox parameters were determined by the coefficient of Pearson. One-way analysis of variance (ANOVA) was carried out in Microsoft Excel 2003. Differences at $P £ 0.05$ were considered statistically significant. The significance of the correlation coefficient was tested by t-test.

\section{Results and discussion}

Antioxidant capacity measured as the ferric reducing ability of fruit extracts ranged between 5.99 and $63.10 \mathrm{mmol}$ AA/100 g FW, with an average value of $26.45 \mathrm{mmol} \mathrm{AA} / 100 \mathrm{~g}$
(Figure 1). In general, the antioxidant capacity was higher in intact fruits than in peeled fruit extracts. Differences between the antioxidant capacities of intact and peeled fruit varied according to genotypes. It must be considered that peels form only a small portion of the fruit weight although its influence seems crucial to antioxidant capacity of whole fruits. In case of 'Bereczki' and 'Bereczki bőtermő', difference was not detected between FRAP values of intact and peeled fruits, which must be further studied.

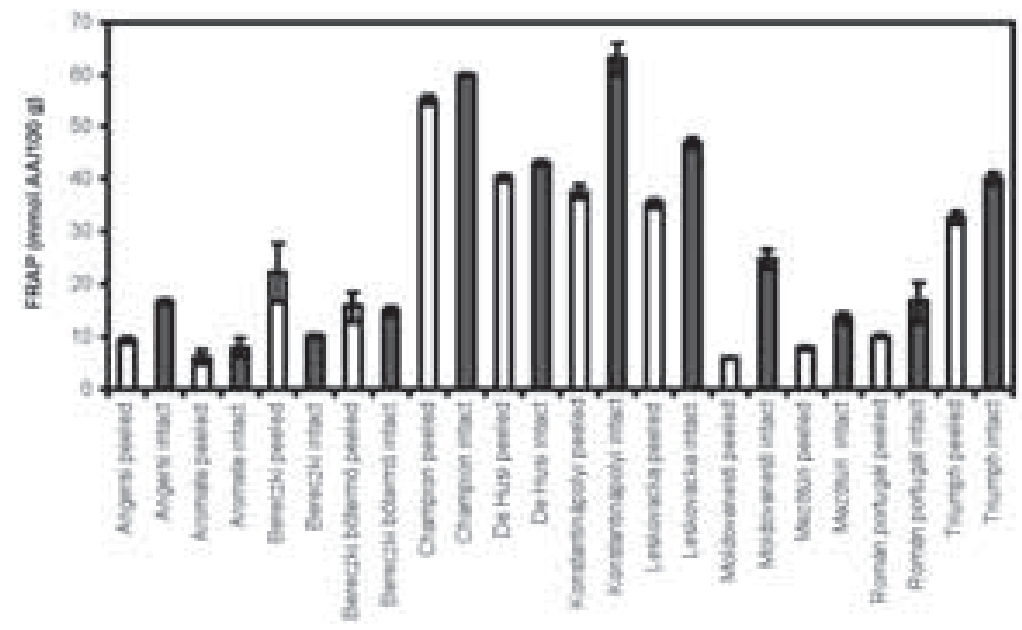

Figure 1 Antioxidant capacity in peeled (white columns) and intact (grey columns) fruits of Cydonia oblonga genotypes harvested in 2010, Újfehértó, Hungary

The antioxidant capacity of intact fruits ranged between 8.02 and $63.10 \mathrm{mmol} \mathrm{AA/100} \mathrm{g.} \mathrm{This} \mathrm{range} \mathrm{represents} \mathrm{an}$ almost 8-times variation among the tested genotypes. The lowest FRAP values were measured in fruits of the 'Aromate' and 'Bereczki' cultivars, while the highest values were obtained for cultivars 'Champion' and 'Konstantinápolyi' .

The total phenolic contents in samples ranged between 3.92 and $12.83 \mathrm{~g} \mathrm{GA} / 100 \mathrm{~g} \mathrm{FW}$, with an average value of 7.74 g GA/100 g (Figure 2). Interestingly, the total polyphenolic content of fruits was again very similar in case of 'Bereczki' and 'Champion'. Phenolic contents in intact fruits ranged

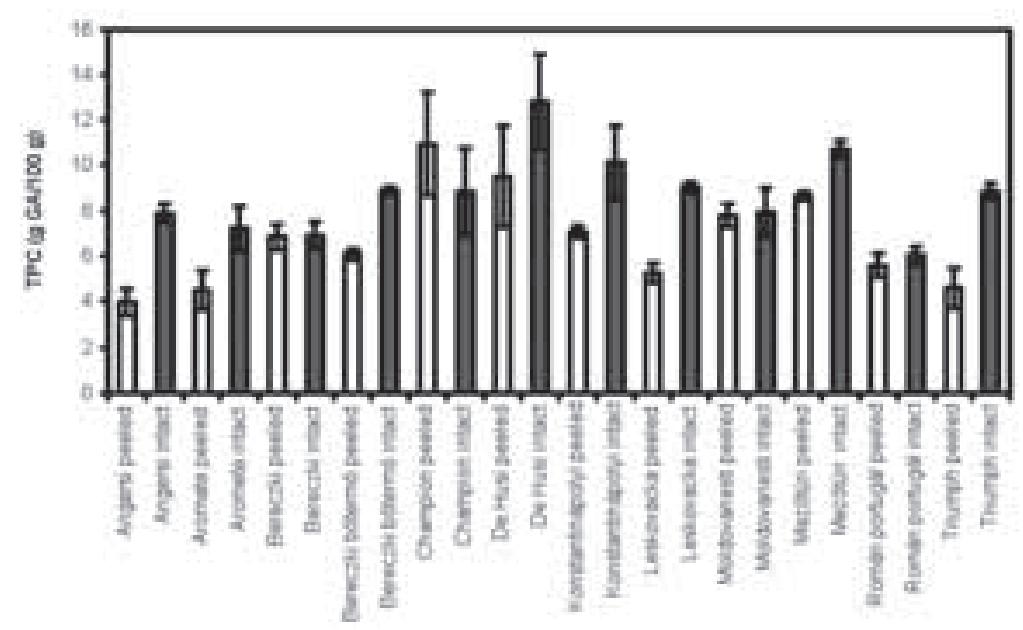

Figure 2 Total phenolics content in peeled (white columns) and intact (grey columns) fruits of Cydonia oblonga genotypes harvested in 2010, Újfehértó, Hungary 
between 6.01 ('Román portugál') and 12.83 g GA/100 g ('De Husi'), presenting two-times variation among the genotypes. The most popular Hungarian cultivar, 'Bereczki', was also characterized by low polyphenolic content, while a Hungarian local selection, 'Mezőtúri', accumulated relatively high quantities of polyphenolics.

Since cultivars showing the lowest and highest antioxidant capacity and total polyphenolic content were not identical, it was interesting to run a correlation analysis to characterize the influence of quince polyphenolics to the antioxidant power of fruit. The Pearson's coefficient was relatively moderate $(r=0.51)$ compared to other species (CevallosCasals et al., 2006; Hegedüs et al., 2008; 2010; Papp et al., 2010, 2011; Yildiz et al., 2010). However, the t-test confirmed a significant correlation between FRAP and TPC values measured in quince fruit.

Our results led us to the conclusion that the fruit of Cydonia oblonga might be considered as a rich source of antioxidants and polyphenolics, especially cultivars 'Champion', 'Konstantinápolyi' and 'De Husi'. In addition, contribution of peel polyphenolics to the antioxidant capacity of whole fruits seems to be a genotype-dependent trait for quince.

\section{Acknowledgements}

This work was financed by the OTKA K84290 grant. Attila Hegedüs is grateful for receiving a János Bolyai Scholarship, Hungarian Academy of Sciences.

\section{References}

Alesiani, D., Canini, A., D'Abrosca, B., DellaGreca, M., Fiorentino, A., Mastellone, C., Monaco, P. \& Pacifico, S. (2010): Antioxidant and antiproliferative activities of phytochemicals from quince (Cydonia vulgaris) peels. Food Chem., 118: 199-207.

Benzie, I.I.F. \& Strain, J.J. (1996): The ferric reducing ability of plasma (FRAP) as a measuring of "antioxidant power": The FRAP assay. Ann. Biochem., 239: 70-76.

Bíró Gy. \& Lindner K. (1999): Tápanyagtáblázat. Medicina, Budapest Carvalho, M., Silva, B.M., Silva, R., Valentao, P., Andrade, P.B. \& Bastos, M.L. (2010): First report on Cydonia oblonga Miller anticancer potential: differential antiproliferative effect against human kidney and colon cancer cells. J. Agr. Food Chem., 58: 3366-3370.

Cevallos-Casals, B.A., Byrne, D., Okie, W.R. \& CisnerosZevallos, L. (2006): Selecting new peach and plum genotypes rich in phenolic compounds and enhanced functional properties. Food Chem., 96: 273-280.

Essafi-Benkhadir, K., Refai, A., Riahi, I., Fattouch, S., Karoui, H. \& Essafi, M. (2012): Quince (Cydonia oblonga Miller) peel polyphenols modulate LPS-induced inflammation in human THP1-derived macrophages through NF-кB, p38MAPK and Akt inhibition. Biochem. Biophys. Res. Com., 418: 180-185.
Fattouch, S., Caboni, P., Coroneo, V., Tuberoso, C.I.G., Angioni, A., Dessi, S., Marzouki, N. \& Cabras, P. (2007): Antimicrobial activity of Tunisian quince (Cydonia oblonga Miller) pulp and peel polyphenolic extracts. J. Agr. Food Chem., 55: 963-969.

Hamauzu, Y., Inno, T., Kume, C., Irie, M. \& Hiramatsu, K. (2006): Antioxidant and antiulcerative properties of phenolics from Chinese quince, quince, and apple fruits. J. Agr. Food Chem., 54: 765-772.

Hegedüs, A., Balogh, E., Engel, R., Sipos, B.Z., Papp, J., Blázovics, A. \& Stefanovits-Bányai, É. (2008): Comparative nutrient element and antioxidant characterization of berry fruit species and cultivars grown in Hungary. HortScience, 43: 17111715.

Hegedüs, A., Engel, R., Abrankó, L., Balogh, E., Blázovics, A., Hermán, R., Halász, J., Ercisli, S., Pedryc, A. \& StefanovitsBányai, É. (2010): Antioxidant and antiradical capacities in apricot (Prunus armeniaca L.) fruits: variations from genotypes, years and analytical methods. J. Food Sci., 75 (9): C722-C730.

Papp, N., Szilvássy, B., Abrankó, L., Szabó, T., Pfeiffer, P., Szabó, Z., Nyéki, J., Ercisli, S., Stefanovits-Bányai, É. \& Hegedüs, A. (2010): Main quality attributes and antioxidants in Hungarian sour cherries: identification of genotypes with enhanced functional properties. Int. J. Food Sci. Tech., 45: 395-402.

Papp, N., Szőke, F., Szabó, Z., Nyéki, J., Stefanovits-Bányai, É. \& Hegedús, A. (2011): Preliminary evaluation of selected Prunus spinosa and $P$. insititia genotypes for their nutraceutical properties. Int. J. Hort. Sci., 17 (4-5): 19-22.

Patel, N.C., Rathod, B.K., Shah, V.N. \& Mahajan, A.N. (2011): Cydonia vulgaris pers.: A review on diversity, cultivation, chemistry and utilization. Pharmacia Lettre, 3: 51-61.

Rop, O., Balik, J., Řezniček, V., Jurikova, T., Škardova, P., Salaš, P., Sochor, J., Mlček, J. \& Kramařova, D. (2011): Chemical characteristics of fruits of some selected quince (Cydonia oblonga Mill.) cultivars. Czech J. Food Sci., 29: 65-73.

Shinomiya, F., Hamauzu, Y. \& Kawahara, T. (2009): Antiallergic effect of a hot-water extract of quince (Cydonia oblonga). Biosci. Biotech. Bioch., 73: 1773-1778.

Silva, B.M., Andrade, P.B., Ferreres, F., Domingues, A.L., Seabra, R.M. \& Ferreira, M.A. (2002): Phenolic profile of quince fruit (Cydonia oblonga Miller) (pulp and peel). J. Agr. Food Chem., 50: 4615-4618.

Silva, B.M., Andrade, P.B., Valentao, P., Ferreres, F., Seabra, R.M. \& Ferreira, M.A. (2004): Quince (Cydonia oblonga Miller) fruit (pulp, peel, and seed) and jam: antioxidant activity. J. Agr. Food Chem., 52: 4705-4712.

Singleton, V.L. \& Rossi, J.A. (1965): Colorimetry of total phenolics with phosphomolybdic phosphotungstic acid „reagents”. Am. J. Enol. Vitic., 16: 144-158.

Souci, S.W., Fachmann, W. \& Kraut, H. (2008): Food composition and nutrition tables. Taylor and Francis, London.

U.S. Department of Agriculture, Agricultural Research Service (2012): USDA National Nutrient Database for Standard Reference, Release 25. http://www.ars.usda.gov/ba/bhnrc/ndl

Yildiz, H., Sengul, M., Celik, F., Hegedus, A., Ercisli, S. \& Tosun, M. (2010): Some phytochemical and antioxidant characteristics of wild and cultivated blackberry fruits (Rubus caucesicus). J. Food Agric. Environ., 8: 156-159. 